\title{
SUBMICROSCOPIC STRUCTURE OF ARTICULAR CARTILAGE IN HUMAN EMBRYA SIX TO ELEVEN WEEKS OLD
}

\author{
D. HORKÝ \\ Department of Anatomy, Histology and Embryology, University of Veterinary \\ Science, 61242 Brno
}

Received April 27, 1989

\begin{abstract}
Horký D.: Submicroscopic Structure of Articular Cartilage in Human Embrya Six to Eleven Weeks Old. Acta vet. Brno, 60, 1991: 15-30.

Articular cartilage of 15 and 19 males and females at the age of 6 to 11 weeks afterfertilization was studied by transmission electron microscopy and scanning electron. microscopy respectively. All specimens were taken from the head of the hip joint, in the youngest individuals the whole head was use 1 . The material was obtained from. abortions and spontaneous miscarriages and was processed by routine meihods.

Although the development of articular cartilage is a continuous process, certain stages can nevertheless be distinguished where changes in the submicroscopic. structure of $i \mathrm{~s}$ individual components and the forming of its surface are reflected most clearly. One of such periods is the 6th and 8th to 11th weeks after fertilization.

In the 6th week, the femur head attains its final configuration. Although the femur primordium as a whole is in the stage of a cartilaginous model, we did observe first ossification centres in some casse. In the cartilaginous primordium of the femur head, the borderline between articular cartilage and the future subchondral bone cannot be distinguished. The character of articular cartilage is that of little-differentiated. tissue. Cells have a uniform appearance of the cells produced by the mesenchyme and the major part of intracellular matter is made up of its amorphous component; the: fibrous component is represented by aperiodic fibrils.

The changes in chondroblasts and intracellular matter taking place between the 8th week allow three basic cartilaginous layers to be distinguished on the basis of the submicroscopic structure of its components from this period on. On the surface chondrosynovial membrane is formed. Viewed under the scanning electron microscope, the cartilaginous surface in the period between the 6 th and 11th week after fertilization is considerably uneven. Chondroblasts are prominent above the surface and between the 8th and 11th week they get arranged into lines or groups.
\end{abstract}

Ultrastructure, human articular cartilage, prenatal development

Articular cartilage if formed from the mesenchyme during the development of the skeleton as: a part of the cartilaginous blastema of the bone primordium, which is made into definite bone in the course of ossification. From the developmental, microscopic and functional points of view, articular cartilage is a part of the joint, which is in fact a specifically differentiated cleft derived from the mesenchymal blastem3. The cartilage formed is almost perfectly adapted to perform its. function in the organism's locomotion. During ossification, the preformed bone primordium is gradually removed. Articular cartilage is not affected by this process and remains intact in the direction of the joint cavity (Bonucci 1967; Scherft 1972; Thyberg 1973 a, b; Ali 1976; Anderson and Sajdera 1976; Felix and Fleisch 1976; Hanaoka 1976).

The process of mesenchymal condensation into blastema takes place in an early stage of embryogenesis. For example, according to Gardner and O'Rahilly (1968) the femoral chondrification begins already in the 6th week after ovulation and in the 8th week the primordium of joint cavity first appears (Sting1 1982). Simultaneously with this process, blood vessels grow into. 
the cartilaginous primordium from perichondrium (Haines 1933; Hurrel 1934; Levene 1964; Lufti 1970, Stockwell 1971; Agraval et al. 1984). They do not, however, penetrate to the region of the future articular cartilage (Gray and Gardner 1969; Gardner and Gray 1970) and disappear in around the 10th week. Before the joint cavity is formed, a fairly large number of tiny cavities appear in the mesenchyme in the contact area of the future articular surfaces of bones. Its formation is assisted by the first muscles and ligaments in the joint region (Drachman and Sokoloff 1966) and perhaps also the first movements (Glenister 1976). According to Godman et al. (1960), Gould et al. (1974) and Levitt and Dorfman (1974), the cells attain their characteristic positions as a result of the continuing chondrification process. We should, however, add that all the above works deal with the question of the development of the human articular cartilage only marginally and limit themselves usually to general statements of well-known facts.

That is why we decided to attempt as comprehensive survey as possible of the ultrastructure of cells and intercellular matter of the human articular cartilage in the prenatal period, including data on the formation of its surface. We focused our main attention on those stages which best reflect the submicroscopic changes of individual components of the articular cartilage which results from its continuous differentiation.

\section{Materials and Methods}

To study the ultrastructure of articular cartilage in transmission electron microscopy we took -specimens of the tissue from the hip joint of 15 individuals of both sexes, whose age was 6 to 11 weeks after fertilization. The material was mostly obtained from abortions and only individuals from later stages were obtained from spontaneous miscarriages. Specimens were taken from the convexity of the femure head while in the case of younger developmental stages the whole head was used. Specimens were split into blocks of $1 \times 1 \times 2-3 \mathrm{~mm}$ and fixed immediately in $300 \mathrm{mmol} /$ /1 or $400 \mathrm{mmol} / 1$ glutaraldehyde solution in phosphate buffer at $\mathrm{pH} 7.4$ for four hours. For a subsequent fixation, $40 \mathrm{mmol} / 1$ solution of $\mathrm{OsO}_{4}$ in phosphate buffer at $\mathrm{pH} 7.4$ for $60 \mathrm{~min}$ was used. Routine methods were used for the dehydratation, immersion and embedding in Durcupan ACM. Tissue sections were made on Ultracut Reichert ultramicrotome and stained with lead citrate or uranylacetate followed by lead citrate. The sections thus obtained were studied and photographed by electron microscope Tesla BS 500 . Semithin sections for light microscopy were stained with methylene blue and Azur II.

For scanning electron microscopy of articular cartilage, specimens $5 \times 5 \mathrm{~mm}$ including a part - of the subchondral bone were taken from 19 individuals. Prior to fixation, they were left for $15 \mathrm{~min}$ in a $0.1 \mathrm{mg} / \mathrm{ml}$ hyaluronidase solution at $20^{\circ} \mathrm{C}$, or were washed for $3 \times 15 \mathrm{~min}$ in saline. If hyaluronidase was used, the specimens were washed in saline for $3 \times 15 \mathrm{~min}$ and then fixed in $10 \%$ formol or glutaraldehyde for 10-14 days. When fixation was concluded, the tissue was drained using the method of drying at a critical point, evaporated with gold (Balzers) and its surface was studied and photographed using a scanning electron microscope Stereoscan Cambridge. The age, sex and numbers of individuals examined are summarized in Table 1.

Fig. 1 to 11 are placed on Plates V1I to XVI at the end of this volume.

Table 1

Age, Sex and Numbers of Individuals Examined by TEM and SEM

\begin{tabular}{|l|lllllllll|}
\hline Age (weeks) & & 6 & & & 8 & & 9 & & 11 \\
Sex & M & F & M & F & M & F & M & F \\
TEM & 2 & 3 & 2 & 2 & 1 & 2 & 3 & 1 \\
SEM & 3 & 4 & 3 & 2 & 1 & 2 & 2 & 2 \\
\hline
\end{tabular}

$\mathbf{M}=$ male, $\mathbf{F}=$ female 


\section{Results}

Ultrastructure of Articular Cartilage in the 6 th Week after Fertilization

In this period, articular cartilage is an undifferentiated part of the bone primordium which grows from the mesenchyme, and has all the characteristics of immature tissue. The cells bear a conspicuous resemblance to, e.g., fibroblasts and there is a large amount of intercellular matter among them, where the amorphous component predominates over the fibrous component.

\section{Submicroscopic Structure of Chondroblasts}

At this stage, chondroblasts are cells uniform in appearance, spindle-shaped and up to $15 \times 5 \mu \mathrm{m}$ in size. They are positioned with their long axis parallel to the surface of articular cartilage (Plate VII., Fig. 1, Plate VIII., Fig. 2), lying in several layers on top of each other.

The nucleus of chondroblasts is an elongated oval (Fig. 1) or even rod-like in shape (Fig. 2), making a nearly perfect copy of the shape of the cell itself.

The nuclear envelope consists of two membranes which only rarely form shallow folds. The perinuclear space is narrow over most of the nucleus circumference. It widens only rarely, with its outer membrane passing into broad cisternae of the granular endoplasmic reticulum (Figs 1, 2, Plate IX., Fig. 3). Nuclear pores are infrequent (Fig. 2). Ribosomes are only rarely attached onto the outer membrane of the nuclear envelope. The zonula nucleum limitans, if formed, abuts as a very narrow strip of medium osmiophilic granulated matter to the inner membrane of the nuclear envelope.

Nuclear sections show diffusely distributed chromatin, which on rare occasions forms small karyosomes (Figs 1, 2), adhering to the nuclear envelope.

Nucleoli are a frequent finding in the nucleus of chondroblasts. We usually observed one nucleolus of the reticular type near the nuclear envelope. In its vicinity lies a district of perinucleolar chromatin (Fig. 2).

Cytoplasm

A characteristic feature of cytoplasm in chondroblasts of this period of development is a relatively small number of cellular organelles and cytoplasmatic inclusions (Figs 1-3).

Granular endoplasmic reticulum is arranged in the form of infrequent cisternae or vesicles (Figs 2,3), which are usually considerably dilated and filled with light material of meshwork appearance. They were frequently observed adhering to the outer membrane of the nuclear envelope (Figs $1-3$ ). Occasional cisternae and vesicles are attached by ribosomes. Structures of granular endoplasmic reticulum occur in various parts of cytoplasm, appearing also in places with stored glycogen (Fig. 3).

Agranular endoplasmic reticulum was observed only very rarely. When present, it took the shape of small smooth vesicles, which probably come into being by fission from the Golgi complex, or by invagination of the cell membrane if they appear close to the cellular surface (Fig. 3).

A relatively large part of cytoplasm of chondroblasts is taken up by Golgi complex. It is formed by a typical diktyosome with Golgi large and small vesicles. The character of the large vesicles is that of transport vacuoles because 
they often contain granulated, medium-osmiophilic material and occur in the vicinity of the cell membrane (Fig. 3).

Mitochondria are far from numerous. We can come across strikingly smalf mitochondria $(0.1 \mu \mathrm{m})$ with cristae of a common arrangement, or mitochondria from 0.5 to $1 \mu \mathrm{m}$ with cristae in the form of tubuli (Fig. 1). No mitochondrial corpuscles were detected.

Ribosomes are attached to the membranes of granular endoplasmic reticulum. Unattached ribosomes in cytoplasm are rare (Figs 2, 3).

We observed no lysosomes, centrioles or microtubules in the cytoplasm of chondroblasts of this stage of development.

Cell membrane. In some cases, cytoplasm of chondroblasts situated near the surface of articular cartilage forms short processes of up to about $0.5 \mu \mathrm{m}$ long, covered with cell membrane (Fig. 2). They are simple processes extending into the surrounding intercellular substance and in between them the surface of cells is smooth (Figs. 1, 2). It is only in chondroblasts which are situated deeper below the surface (Fig. 3) that the processes are more numerous and are about $0.8 \mu \mathrm{m}$ in length. We observed no pinocytotic vesicles either in surface or deep layers of localized chondroblasts.

We found no support structures or cilia in our material from this stage of development.

In cytoplasm of chondroblasts, glycogen occurs regularly both in the surface and deep layers, even though in small quantities only. It is present there in the form of individual beta granules, primarily in the cytoplasm district near the nucleus (Figs 1,3 ) and may even form small deposits in the more deeply situated. chondroblasts.

We observed no lipid droplets or cytoplasmic fibrous structures.

\section{Arrangement of Intercellular Substance of Articular Cartilage}

Intercellular substance of articular cartilage in this stage of development is composed of a fibrous component and ground amorphous substance. In this stage of development the fibrous matter is represented only by aperiodic fibrils that are situated in abundant amorphous substance. The surface of articular cartilage is created in two ways. In the first case (Fig. 1) chondroblasts are overlaid with a relatively thick layer of intercellular substance of up to $8-10 \mu \mathrm{m}$.

Electronograms clearly show that near the surface aperiodic fibrils form tiny bundles radiating in various directions, so that we can observe them both in longitudinal, tangential and cross-sections. Aperiodic fibrils on the surface are not overlaid with amorphous substance, coming thus into direct contact with the joint cavity. In some districts immediately next to the surface we observed large vesicles bounded by a smooth membrane (Fig. 1), which were either electron-optically empty or filled with medium osmiophilic material, and fissures in the intercellular substance. Moreover, loose glycogen granules may also be observed among bundles of aperiodic fibrils. Both vesicles and glycogen come from desintegrated chondroblasts or this layer. A region of future pericellular matrix is being formed around cells under thus created surface.

In the second case, chondroblasts are located immediately next to the surface of articular cartilage and are overlaid with a rather discontinuous thin layer of intercellular substance formed by a few bundles of aperiodic fibrils with a small amount of amorphous substance (Fig. 2). Narrow spaces between laminarly patterned chondroblasts are filled with irregularly arranged meshworks of ape- 
riodic fibrils, representing an area of intercellular matrices which are in a close contact with the cell membrane of chondroblasts (Fig. 2). It is only on the opposite side to the surface that a narrow pericellular space is formed with occasional aperiodic fibrils and abundant amorphous substance.

Chondroblasts of the deeper layers (Plate IX., Fig 3) are surrounded by a pericellular matrix, which forms a lighter zone near the cell membrane of chondroblasts. In the pericellular matrix zone, small amounts of aperiodic fibrils occur but ground amorphous substance is predominant. Behind the layer of pericellular matrix there is some intercellular substance consisting of a denser network of aperiodic fibrils, radiating in various directions. We detected no typical collagenous fibrils.

\section{Ultrastructure of Articular Cartilage Between 8 th and 11 th Week After Fertilization}

At this stage of development, the number of chondroblasts in the area begins to grow. This is particularly true about the surface layer, where cells predominate over intercellular substance. Deeper below the surface, some of the cells already acquire certain characteristics of chondrocytes.

\section{Submicroscopic Structure of Surface-Layer Chondroblasts}

Like cells of the previous stage of development, chondroblasts of the surface layer are strikingly flat, spindle-like with an elongated profile, and are up to $15 \times 4 \mu \mathrm{m}$ in size. They are situated in several layers, in places tightly agglutinated, with their longitudinal axis parallel to the surface (Plate X., Fig. 4, Plate XI., Fig 5). Chondroblasts very often extend above the surface of articular cartilage, which may be covered either with their long and flattened cytoplasmic processes or a layer of intercellular substance in the direction of articular cartilage (Fig. 4).

\section{Nucleus}

Nuclei of chondroblasts of the surface layer have the shape of very elongated ovals or, in some cases, of rods (Figs 4, 5).

Nuclear envelopes have a usual structure and do not as a rule extend against the karyoplasm. The perinuclear space is narrow and we observed no connection between the external membrane of the nuclear envelope and cisternae of the granular endoplasmic reticulum. Ribosomes are only rarely attached to the external membrane. Zonula nucleum limitans has the shape of a very narrow band of granulated appearance attached to the internal membrane of the nuclear envelope (Fig. 4).

Sections of the nucleus show that chromatin is agglutinated either in the form of tiny karyosomes close to the nuclear envelope or in an irregular pattern over the nuclear section. In places of nuclear pores, lighter districts can be distingusshed in chromatin (Fig. 4).

Nucleoli, in contrast to chondroblasts of the previous stage, are rarely found. When we found any at all, they were nucleoli of the reticular type, while ring-like nucleoli were very exceptional indeed (Fig. 5).

\section{Cytoplasm}

In this stage of development, cellular organelles in the cytoplasm of surface layer chondroblasts have multiplied, while cytoplasmatic inclusions have disappeared. 
Granular endoplasmic reticulum takes the shape of broadly dilated cisternae, which are filled with material of medium electron density arranged in web-like patterns (Figs 4, 5). Ribosomes are attached in great numbers to their membranes. In view of cell configurations, its structures occur mainly in peripheral parts of cells (Figs 4,5 ).

Agranular endoplasmic reticulum only occurs in the cytoplasm of several chondroblasts near the cell membrane (Fig. 4) in the form of several smooth vesicles of $0.5 \mu \mathrm{m}$ in size.

Golgi complex is not very prominent, taking up only a small area and can only rarely be observed.

Mitochondria are of a usual architecture and in sectioned material they as a rule exhibit an oval profile (Figs 4,5 ). They attain the size of $0.6-1 \mu \mathrm{m}$. Besides mitochondria of this architecture, circular mitochondria occur from time to time, they are $0.8-1.2 \mu \mathrm{m}$ in size, with thinly distributed leaf-shaped cristae and conspicuously light matrix (Fig. 4). These are probably damaged mitochondria.

In contrast to the previous stage, ribosomes are very numerous and large amounts of them are scattered diffusely in the cytoplasm, forming rosette-shaped polyribosomes (Fig. 4).

In the material from this stage of development we observed no lysosomes, microtubules or centrioles.

Cell membrane. Along the whole of circumference of the surface layer chondroblasts is covered with cell membrane which is slightly undulating and contains either no processes at all (Fig. 4) or only discrete, strikingly long and massive processes which maintain the contact between individual cells (Fig. 5). In some sections, collagenous fibrils lean closely to them and in some cases they penetrate through the cell membrane (Fig. 4).

We found no support structures or cilia in surface layer chondroblasts.

Lipid droplets occur only very rarely (Fig. 4). They are bounded with a smooth membrane and attain the size of up to 1.2 to $1.5 \mu \mathrm{m}$.

In contrast to the previous stage, chondroblasts of this layer contain no glycogen.

Cytoplasmic fibrous structures in cytoplasm occur in some chondroblasts as discrete bundles of filaments in the vicinity of the nuclear envelope (Fig. 4). They never form any continuous border along the nucleus. Besides these filaments $8-10 \mathrm{~nm}$ in size, we occasionally observed more massive bundles of osmiophilic fibrils on cellular peripheries, whose size and density were identical with collagenous fibrils in the intercellular substance (Fig. 4).

Submicroscopic Structure of the Middle-Layer Chondroblasts

In the 8th to 11 th week after fertilization, chondroblasts of the middle layer usually manifest an oval profile, attaining $8 \times 10-12 \mu \mathrm{m}$ in size. They are discretely located in intercellular substance, only rarely in pairs (Plate XII., Fig. 6, Plate XIII., Fig. 7).

\section{Nucleus}

Nuclei of the middle-layer chondroblasts are of a rounded profile and relatively large, attaining $5 \times 6 \mu \mathrm{m}$ in size.

The nuclear envelope consists of two membranes, separating the karyoplasm from cytoplasm. Its membranes exhibit no major irregularities, with minor 
indentations in some places only (Fig. 7). The outer membrane has a few ribosomes bound to it. The perinuclear space is narrow and it is only very exceptionally that the outer membrane of the nuclear envelope passes into cisternae of the granular endoplasmic reticulum. The number of nuclear pores is not very large.

Nuclear sections show chromatin diffusely distributed, forming small karyosomes near the inner membrane of the nuclear envelope only (Fig. 6), or its arrangement is similar to that of surface-layer nuclei (Fig. 7). Zonula nucleum limitans is a narrow band interrupted in places of nuclear pores (Fig. 7).

As in the surface-layer chondroblasts, nucleoli occur very rarely.

\section{Cytoplasm}

Compared to chondroblasts of the previous layer, cytoplasm occur in larger amounts, contains a larger number of organelles and some cytoplasmic inclusions, particularly glycogen (Fig. 6).

Compared to surface layer cells, granular endoplasmic reticulum is arranged in the form of flattened cisternae, whose ends widen and form vesicles (Figs 6,7). In some areas of cytoplasm, reticulum profiles are arranged laminarly, in other places individual narrow cisternae extend in an irregular fashion among other organelles (Fig. 7). In both cases, ribosomes are bound in large numbers to its membranes and its inner space is filled with fibrillar material of medium electron density. In dilated cisternae, this material thickens in places and may even attain a granulated appearance (Fig. 6). It is particularly these dilated cisternae of granular endoplasmic reticulum that are interconnected by broad junctions (Fig. 6).

Agranular endoplasmic reticulum occurs only very rarely in the form of small vesicles at the cytoplasm periphery in the vicinity of Golgi complex, so that they most probably represent split-off vacuoles.

Golgi complex (Fig. 6) is very extensive and takes up a considerable part of cytoplasm. It is distributed over up to five fields arranged in a circle. A large number of vesicles from $80-100 \mathrm{~nm}$ to $0.7 \mu \mathrm{m}$ in size split-off diktyosomes of a usual arrangement. The centre of the area bounded by Golgi fields is crowded with small vesicles, while vesicles of a larger size occur mainly at its periphery. Both small and large vesicles, and in particular the latter, contain fibrillar or even granular material of the same density as the cisternae of granular endoplasmic reticulum and have a character of transport vacuoles (Figs 6,7).

Mitochondria are rounded or oval in shape, more numerous than in the cytoplasm of chondroblasts in the previous layer and attain the size of 0.5 to $0.8 \mu \mathrm{m}$ in cross-sections. Their cristae are thinly distributed and besides mitochondria of the usual appearance, mitochondria with disintegrated cristae and cleared-up matrix occur from time to time (Figs 6,7).

Ribosomes are mostly bound to membranes of the granular endoplasmic reticulum. We hardly ever encountered any free ribosomes.

Lysosomes are a rare finding in cytoplasm of middle-layer chondroblasts (Fig. 7).

Cell membrane. Cytoplasm extends in short unbifurcated processes along the whole of the cellular circumference (Fig. 6). These processes, which are up to $1.5 \mu \mathrm{m}$ in size, are covered with cell membrane and extend into the surrounding intercellular substance.

We observed no support structures or cilia in middle-layer chondroblasts. 
Glycogen forms a regular part of cytoplasm of the chondroblasts in this layer. It is made up of characteristic beta granules, either agglutinated in several small districts or taking up a somewhat larger area at one pole of the cell (Figs 6, 7), with further clusters occurring in various places in cytoplasm.

\section{Submicroscopic Structure of Deep-Layer Chondroblasts}

Deep layer chondroblasts are usually more varied in shape than cells of the previously discusse layers. They usually have an oval, spindle-like elongated or even star-like shape (Plate XIV., Fig. 8). They more frequently occur in groups or pairs (Plate XV., Fig. 9) and between the closely adjoining cells, we can find cell membrane contact zones of various width. Cells are somewhat smaller than in the middle layer, attaining the size of $8-10 \times 6 \mu \mathrm{m}$.

\section{Nucleus}

Nuclei of the deep-layer chondroblasts are of an oval or slightly elongated profile (Fig. 9), attaining the size of $5 \times 3 \mu \mathrm{m}$, or of irregularly lobular shape (Fig. 8).

The nuclear envelope has a usual structure. In the case of pairs of chondroblasts, it is smooth, forming no invaginations against karyoplasm (Fig. 9). In the case of nuclei of chondroblasts agglutinated in groups, its invagination is often very deep, giving the nuclei an irregular or even lobular appearance (Fig. 8). The perinuclear space is narrow and junctions between the outer membrane of the nuclear envelope and cisternae of granular endoplasmic reticulum were observed only rarely.

In sectioned material, chromatin in nuclei is arranged in karyosomes (Figs $8,9)$, either bound to the inner membrane of the nuclear envelope or distributed in an irregular manner over the nuclear cross-section. Zonula nucleum limitans is formed in the same way as in nuclei of the middle-layer chondroblasts.

\section{Cytoplasm}

Compared to middle-layer chondroblasts, cytoplasm occurs in smaller quantities and contains fewer organelles. Cytoplasmic inclusions are represented by glycogen (Figs. 8, 9).

Granular endoplasmic reticulum in cytoplasm occurs in the form of flat cisternae and single vesicles between them (Figs 8,9). In view of the fact that cytoplasm forms only a narrow border around nuclei of paired chondroblasts, cisternae of the reticulum are positioned in the vicinity of the nucleus parallel to its surface (Fig. 9). In cytoplasm of chondroblasts in groups, the number of its structures is larger and they are mostly positioned at the periphery of cytoplasm. The ribosomes bound to its membranes are numerous, and inner spaces are filled up with amorphous material of medium electron density (Fig. 9). In some cases, cisternae have among them vesicles of up to $0.6 \mu \mathrm{m}$ in size containing granulated material of a higher density than the cisternae. They may be either split-off parts of cisternae of granular endoplasmic reticulum, or, more likely, of the so-called transport vacuoles, arising from the vesicles of Golgi complex.

We observed no agranular endoplasmic reticulum in deep-layer chondroblasts.

Golgi complex is not very prominent and if detected at all, it takes up only a small district of cytoplasm, often at the periphery of the cell. Its diktyo- 
some is small, with tiny vesicles and larger vacuoles with granulated content separating from it (Fig. 8).

Mitochondria are not numerous, have a standard arrangement and attain the size of 0.3 to $0.6 \mu \mathrm{m}$.

For the most part, ribosomes are bound to membranes of the granular endoplasmic reticulum and it is only rarely that we come across any free ribosomes in cytoplasm.

We observed no lysosomes, microtubules or centrioles in cytoplasm of chondroblasts.

Cell membrane. With the exception of the contact region between cells, cytoplasm extends along all of its circumference into short, unbifurcated processes covered with cell membrane (Figs 8,9 ). The processes, not exceeding $1 \mu \mathrm{m}$ in length, reach into the intercellular substance where we can even meet with their cross-sections (Fig. 9). In areas where cells adhere to each other, cellular membranes of adjoining cells exhibits no major irregularities, creating wider intercellular spaces in certain areas only. Some segments of closely adjoining cellular matter exhibit higher osmiophilic characteristics, the intercellular space is reduced and signs of zonula adherens (Fig. 9) appear. The arrangement of cytoplasmic processes in the vicinity of contacts between neighbouring cells and the creation of a contact zone is highly suggestive of daughter cells in late telophase.

Glycogen in the cytoplasm of deep-layer chondroblasts occurs regularly and has the same appearance as in middle-layer cells, the only exception being that it occurs in large deposits (Figs 8,9 ).

\section{Arrangement of Intercellular Substance of Articular Cartilage}

In contrast to the previous stage, the fibrous component of intercellular substance of articular cartilage in the period between the 8th and 11th week of development consists of fibres of two types. They are on the one hand aperiodic fibrils of the same appearance as in the 6th week after fertilization and, on the other hand, typical collagenous fibrils that appear for the first time (Fig. 4) Collagenous fibrils occur primarily in the surface layer, while in the middle and deeplayers their amount is very small and, like in the previous period, aperiodic fibrils in amorphous substance predominate (Figs 6-9).

The surface of articular cartilage is formed by a $0.1-0.2 \mu \mathrm{m}$ thick layer composed of aperiodic fibrils set in amorphous substance (Fig. 4). Besides aperiodic fibrils, also occasional collagenous fibrils occur below this boundary layer, and penetrate sporadically into its immediate vicinity (Fig. 4). Radiating in various directions, they can be found both in longitudinal sections and in cross-sections. Among surface-layer chondroblasts, we can detect the presence of not only the amorphous substance but also of fibrils of both types. In some cases collagenous fibrils penetrate the cellular matter (Fig. 4). The pericellular district is not clearly formed yet.

In the middle and deep layers (Figs 6-9), intercellular substance is formed by aperiodic fibrils with a large amount of amorphous substance, while collagenous fibrils occur only rarely. The appearance and arrangement of the pericellular matrix is the same as in the previous period. 
Scanning Electron Microscopic Appearance of Articular Cartilage

Results of the study of the surface of articular cartilage in individual stages of development showed that the changes in its arrangement closely corresponded to ultrastructural findings. The greatest changes take place in the period between approximately the 8th and 11th week after fertilization.

In the period up to the 8th week of development, the surface of articular cartilage is very uneven (Plate XVI., Fig. 10) and varied. Numerous semispherical or spindle-shaped elongated ridges with shallower or deeper grooves between them are prominent above level of the cartilage. Both the prominences and the areas between them are deeply furrowed, while the grooves are more or less smooth.

The 11th week of development marks the appearance of small groups of chondroblasts that are prominent above the surface as spindle-shaped ridges. It becomes clear under greater magnification that their surface is full of tiny processes that lend a granular appearance to these structures (Plate XVI., Fig. 11). The niveau above which these prominences rise exhibits mound-like structures radiating in all directions (Figs 10,11). In some cases, several lines of them lie parallel to each other (Fig. 19). The ground structure for the ridges are the uppermost chondroblasts, while the mounded surface is the intercellular substance of articular cartilage or, in some later stages, folds of chondral membrane.

\section{Discussion}

Light microscopic studies of early ontogenetic development of articular structures in man have been made by a large number of authors (Gray et al., 1957; Gardner and O'Rahilly 1968; Čihák 1972; O'Rahilly and Gardner 1975, Glenister 1976; Levitt and Dorfman 1974, inter alia). It follows from these works that articular surfaces as well as other joint components come into existence in the period between the 6th and 10th week after fertilization and that the joint cavity appears in the 8th week (Gardner and O'Rahilly 1968). No information, however, exists on the prenatal development of the submicroscopic structure of human articular cartilage.

In our set of human embrya we found a cavity of the hip joint from the 6th week after fertilization. This observation is in fairly good agreement with the data published by Gardner and O'Rahilly (1968), who focused their attention on the knee joint. If we take into account the differences in the proximodistal sequence, then our observation does not contradict these data. Moreover, certain inaccuracies in the. determination of the length of pregnancy and the crown-rump length should be taken into consideration.

In the study of articular cartilage in not only man but also lower mammals (Horký 1983; 1986; 1987) we found that certain periods can be distinguished in the dynamics of the prenatal development when distinct changes in the ultrastructure of cells and in the qualitative and quantitative composition of intercellular substance and its arrangement take place.

In the 6th week, the primordium of the femoral head is completely composed of cartilage and the joint cavity has already been formed, which was also confirmed by O'Rahilly and Gardner (1975). In this stage, the cartilaginous primordium has all the characteristics of an immature cartilaginous tissue. Cells 
are uniform in their appearance both on the surface and in a deeper zone, they: are set in an abundant intercellular substance with a predominance of its amor-. phous component. Intercellular substance produced by chondroblasts (Sheldon and Kimball 1962) is arranged in a different way on the surface of articular cartilage, where it is formed by somewhat denser layer composed of aperiodic: fibrils.

In man, important changes in the ultrastructure of articular cartilage take place in the period between the 8th and 11th week of intrauterine development. While the appearance of cells in the surface layer does not change in any significant way, some cells deeper under the surface attain characteristics of differentiated elements. With a certain approximation, these changes can be used as a basis. for distinguishing three layers in articular cartilage of an adult man and experimental mammals (Palfrey and Davis 1966; Weiss et al. 1968; Vignon et al. $1976 ;$ Horký $1980 ; 1983 ; 1986 ; 1987)$. In the surface and middle layers, cells are oriented parallel to the surface of the cartilage (Godman et al. 1960; Gould. et al. 1974; Levitt and Dorfman 1974). According to these authors, this is because they are transferred from the region of the chondrification center, while Clark (1971 a; b; 1974) and Zimny and Redler (1972) believe that it is the: optimum situation from the mechanical point of view.

As regards the occurrence of blood vessels, they have not been described in any human material and we did not find any in our material, either. This contrasts with the situation in articular cartilage of lower mammals (Horký 1968). Neither did we find canals described by Hurrel (1934), Levene (1964), Lufti. (1970), Stockwell (1971) in deep layers of the primordium of the femoral head, reached by the vessels from the perichondrium. In contrast to papers by Stockwell (1967) and Ghadially (1983), we were unable to confirm an elevated number of mitoses in the middle layer.

An important symptom of differentiation of intercellular substance and thus. also an index of the ability of articular cartilage to perform its function in the: joint is the formation of its surface. In the period investigated, we failed to observe: any signs of fibrillar component densification. In some cases, aperiodic fibrils. began to agglutinate into bundles and it can be clearly seen that collagenous. fibrils are being produced. The surface of articular cartilage is fairly uneven and aperiodic fibrils of the surface layer extend even into the joint cavity. In this period, short segments covered with bundles of fibrillar material of various length and thickness begin to form. They are considered the primordium of the chondral. membrane (Wolf 1946; 1969; 1975; McConnail 1951; Weiss et al. 1968; Meachim and Stockwell 1973; 1979; Stockwell and Meachim 1979; Horký $1980 ; 1983 ; 1986)$. McCutchen (1966) and Maroudas (1973) believethan this structure is formed by ultrafiltration of joint fluid through the surface layer of cartilage. We, on the other hand, assume that the chondral membrane is formed by tropocollagenous bundles of filaments laid along the surface of articular cartilage, without their polymerization into typical collagenous fibrils. As regards centrioles and cilia, we can confirm observations of Scherft and Daems (1967), Stockwell and Meachim (1973; 1979), Horký (1978; 1980). Ghadially (1982; 1983), Vidinov and Vasilev (1985) concerning articular cartilage of both man and lower mammals: all of these authors mention a higher inciderce of centrioles and cilia in young individuals.

In the cytoplasm of chondroblasts in the surface and middle layers of articular cartilage, small amounts of intracytoplasmic filaments begin to appear. 
Their amount increases with age and in adult individuals they may even take up a considerable part of the cytoplasm (Weiss and Mirrov 1972). According to their agglulination in the cytoplasm, some authors assessed the overall metabolic state of cells (Thyberg et al. 1973a; b; Wiltberger and Lust 1975), or the process of cell ageing (Curtiss and Klein 1965; Ghadially et al. 1970; Dearden et al. 1974; Meachim and Fergie 1975), and their quantities during pathological states were studied (see surveys by Horký 1980, Ghadially 1982), because it used to be assumed that it was a tropocollagen (Revel and Hay 1963; Goldberg and Green 1964). In their works, Lazardies (1980), Porter and Tucker (1981) proved that these filaments were made up of various proteins and that the filaments in cartilaginous cells were of the so-called vimentine type. They form a tri-dimensional meshwork, which is present in the cytoplasm during all of its cellular cycle. It is generally assumed that they participate with microtubules (Roberts and Hyams 1979) in determining the shape of the cell. It is still not clear, however, whether they get attached to the cellular membrane.

In the prenatal period, the surface of articular cartilage exhibits considerable changes in its formation. Even when we take into account objections of some authors to the methods of scanning electron microscopy for the study of articular surfaces (Bloebaum and Wilson 1980; Ghadially 1983), we cannot dismiss lightly the large number of new information provided by this study of surfaces. On the basis of as yet published works (Ghadially et al. 1978; Longmore and Gardner 1978; Moschurchak and Ghadially 1978; Puschmann 1978) on experimental animals as well as man (see e. g. comprehensive survey by Ghadially 1983) it is clear that the number of irregularities representing chondroblasts deposited on the surface grows smaller in the course of development and the cartilage surface gets smoother. Our observation is in agreement with the findings published by particularly Moschurchak and Ghadially (1978) and Longmore and Gardner (1975; 1978), who compared their results with findings obtained with interference microscope. It is clear (Horký 1984) that fixation and dehydration artifacts are produced easily particularly in embryonal material because articular cartilage in an early stage of its development contains a considerable amount of water, while proteoglycans and the fibrous component still remain largely unformed (Freeman and Meachim 1973). In the course of development, however, we can observe what could be described as sinking of formerly considerably prominent chondroblasts, separated by a furrow from the surrounding matrix. The furrow is due to a collapse of the newly appearing pericellular matrix, which is at first mainly composed of amorphous substance with a high water content, so that dehydration may cause a collapse of an entire district (Clarke 1971ab, 1974). With increasing amount of the fibrous component in the intercellular substance, the sagging becomes less and less apparent. This is another fact which can to a certain extend provide information on the degree of cartilage differentiation.

\section{Submikroskopická struktura kloubní chrupavky lidských embryí stáři 6-11 týdnů}

Byla studována kloubní chrupavka 15 jedinců obojího pohlaví stáŕi $6-11$ týdnů po oplození $\mathrm{v}$ transmisním elektronovém mikroskopu a 19 jedinců téhož stáŕi $\mathrm{v}$ rastrovacím elektronovém mikroskopu. Vzorky byly odebírány ve všech prrípadech $\mathrm{z}$ hlavice kyčelního kloubu, $\mathrm{u}$ nejmladších byla odebrána celá hlavice. 
Materiál byl získán jednak při interupcích, jednak při spontánních potratech a byl zpracován standardním způsobem.

I když vývoj artikulární chrupavky probihá kontinuálnè, lze vymezit období, kdy se změny $\mathrm{v}$ submikroskopické struktuře jednotlivých komponent i $\mathrm{v}$ utváření jejiho povrchu obrážejí nejzřetelněji. Jedním z těchto období je 6. a 8.-11. týden po oplozeni.

V 6. týdnu nabývá hlavice femuru definitivní konfigurace, přičemž celý základ femuru je ve stadiu chrupavčitého modelu, $v$ některých případech jsme pozorovali první osifikačni body. V chrupavčitém základu hlavice kloubu neni možno rozlišit hranici mezi artikulární chrupavkou a budoucí subchondrálni kostí. Artikulární chrupavka má charakter málo diferencované tkáně. Buňky mají uniformni vzhled buněk vznikajicich $z$ mezenchymu a $\mathrm{v}$ mezibuněčné hmotě převažuje složka amorfni; složka vláknitá je zastoupena aperiodickými fibrilami.

V obdobi 8.-11. týdne dochází ke změnám chondroblastů i mezibuněčné hmoty tak, že od tohoto stadia můžeme $\mathrm{v}$ chrupavce odlišit na základě submikroskopické stavby jejich komponent tři základní vrstvy. $\mathrm{Na}$ povrchu se vytvár̆i chondrosynoviální membrána. V rastrovacím elektronovém mikroskopu je povrch chrupavky $\mathrm{v}$ období 6.-11. týdne po oplození značně nerovný. Nad povrch prominují chondroblasty a $v$ období 8.-11. týdne se organizuji do řad nebo skupin.

\section{Субмикроскопическая структүра сүставного хряща человеческих в первом триместре}

Проводили изучение сүставного хряща 15 особей обоего пола в возрасте 6-11 недель после оплодотворения в трансмиссионном электронном микроскопе и 19 особей того же возраста в растровом электронном микроскопе. Образцы во всех случаях брали с холовки тазобедренного сустава, у самых молодых особей брали головку целиком. Материал получили при прерывании беременности, а также при самопроизвольных абортах, обрабатывая его стандартным способом.

Хотя и развитие суставного хряща протекает непрерывно, можно все же определить периоды, когда изменения субмикроскопической структуры отдельных компонентов и формирование поверхности хряща четче всего отражаются. Одним из упомянутых периодов является 6 и 8 - 11 недели после оплодотворения.

На 6 неделе головка бедренной кости приобретает окончательную конфигурацию, при этом вся основа бедренной кости находится на стадии хрящеватой модели, в некоторых случаях нами наблюдались первые точки оссификации. На хрящеватом основании головки нельзя разлечить предел между сүставным хрящом и будущей субхондральной костью. Суставной хрящ отличается характером малодифференцированной ткани. Клетки по виду совпадают с клетками, возникающими из мезенхимы и преобладающей в межклеточной массе является аморфная составляющая; волокнистый компонент представлен апериодическеми фибриллами.

На 8 - 11 неделе происходят изменения хондробластов и межклеточной массы так, что с данной стадии в хряще можно на основе субмикроскопического строения их компонентов различить три основных 
слоя. На поверхности образуется хондросиновиальная мембрана. В растровом электронном микроскопе поверхность хряща на 6-11 неделе после оплодотворения значительно неровная. Над позерхностью выдвигаются хондробласты и на 8-11 неделе они орханизованы в ряды или группы.

\section{References}

AGRAWAL, P. - ATRE, P. - KULKARNI, D. S.: The role of cartilage canals in the ossification of the talus. Acta Anat., 119, 1984: 238-241

ALI, S. Y.: Analysis of matrix vesicles and their role in the calcification of epiphysal cartilage. Fed. Proc., 35, 1976: 136-142

ANDERSON, H. G.-SAJDERA, S. W.: Calcification of rachitic cartilage to study matrix vesicle function. Fed. Proc., 35, 1976: 148-152

BLOEBAUM, R. D. - WILSON, A. S.: The morphology of the surface of articular cartilage in adult rats. J. Anat. (London), 131, 1980: 333-346

BONUCCI, E.-DEARDEN, L. C.: Matrix vesicles in ageing cartilage. Fed. Proc., 35, 1976: $163-168$

CLARKE, I. C.: Surface characteristic of human articular cartilage - a scanning electron microscope study. J. Anat. (London), 108, 1971a: 23-30

CLARKE, I. C.: Human articular surface countours and related surface depression frequency studies. Ann. rheum. Dis., 30, 1971b: 15-23

CLARKE, I. C.: Articular cartilage: a review and scanning electron microscope study. II. The territorial fibrillar architecture. L. Anat. (London), 118, 1974: 261-280

CURTISS, P. H. - KLEIN, L.: Destruction of articular cartilage in septic arthritis. II. In vivo studies. J. Bone Jt. Surg., 47A, 1965: 1 595-1 614

CIHAK, R.: Ontogenesis of the skeleton and intrinsic muscles of the human hand and foot. Erg. Anat. Entwickl. Gesch., 46, 1972: 1-25

DEARDEN, L. C. - BONUCCI, E.-CUICCHIO, M.: An investigation of ageing in human costal cartilage. Cell Tissue Res., 152, 1974: 305-337

DRACHMAN, D. B. - SOKOLOFF, L. L.: The role of movement in embryonic joint development. Develop. Biol., 14, 1966: 401-420

FELIX, R.-FLEISCH, H.: Role of matrix vesicles in calcification. Fed. Proc., 35, 1976: 169 to 171

FREEMAN, M. A. R.-MEACHIM, G.: Ageing degeneration and remodelling of articular cartilage. In: Adult articular cartilage. Ed. M. A. R. Freeman. Alden Press, Oxford, 1973

GARDNER, E.-O'RAHILLY, R.: The early development of the knee joint in staged human embryos. J. Anat. (London), 102, 1968: 289-299

GARDNER, E.-GRAY, D. J.: The prenatal development of the human femur. Am. J. Anat., 129, 1970: $121-140$

GHADIALLY, F. N.-MEHTA, P. N. - KIRKAI DY-WILLIS, W. H.: Ultrastructure of articular cartilage in experimentally produced lipoarthrosis. J. Bone Jt Surg., 52A, 1970: 1147 to 1158

GHADIALLY, F. N.-MOSHURCHAK, E. M.-GHADIALLY, J. A.: A maturation change in the surface of cat articular cartilage detected by the scanning electron microscope. J. Anat. (London), 125, 1978: 349-360

GHADIALLY, F. N.-YONG, N. K.-LALONDE, J.-M. A.: A transmission electron microscopic comparison of the articular surface of cartilage processed attached to bone and detached from bone. J. Anat. (London), 135, 1982: 685-706

GHADIALLY, F. N.: Fine structure of synovial joints. Butterworths, London 1983

GLENISTER, T. W.: An embryological view of cartilage. J. Anat. (London), 122, 1976: 323-330

GODMAN, G. C.-LANE, N.-PORTER, K. R.: Chondrogenesis. Studies with the electron microscope. J. Biophys. Biochem. Cytol., 8, 1960: 719-732

GOLDBERG, B.-GREEN, H.: An analysis of collagen secretion by established mouse fibroblast lines. J. Cell. Biol., 22, 1964: 227-258

GOULD, R. P.-SELWOOD, L.-DAY, A.: The mechanism of cellular orientation during early cartilage formation in the chick limb and regenerating amphibian limb. Exp. Cell Res., 83, 1974: 287-296

GRAY, D. J.-GARDNER, E.: Prenatal development of the human humerus. Am. J. Anat., 124, 1969: $431-446$ 
GRAY, J.-GARDNER, E.-O'RAHILLY, R.: The prenatal development of the skeleton and joints of the human hand. Am. J. Anat., 101, 1957: 169-223

HAINES, R. W.: Cartilage canals. J. Anat. (Iondon), 68, 1933: 45-64

HANAOKA, H.: The fate of hypertrophic chondrocytes of the epiphyseal plate. An electron microscopic study. J. Bone Jt Surg., 58, 1976: 226-229

HORKÝ, D.: Submicroscopic structure of the human joint cartilage. Acta vet. Brno, 49, 1980: $145-176$

HORKY, D.: Ontogenic development of the ultrastructure of bovine joint cartilage. Acta vet Brno, 52, 1983: 103-130

HORKÝ, D.: Ultrastruktura kloubní chrupavky a synoviální membrány skotu $\mathbf{v}$ ontogeneze. Acta Facult. Med. Univ. Brunensis, 57, 1984: 319

HORKÝ, D.: Ultrastructure of bovine articular cartilage between weeks 8 and 23 of prenatal development. Acta vet. Brno, 55, 1986: 22ı-246

HORKÝ, D.: Submicroscopic structure of bovine articular cartilage in prenatal and early postnatal period. Acta vet. Brno, 56, 1987: 3-18

HURREL, D. J.: The vascularization of cartilage. J. Anat. (London), 69, 1934: 47-61

LAZARIDES, E.: Intermediate filaments as mechanical integrators of cellular space. Nature (London), 283, 1980: 249-256

LEVENE, C.: The pattern of cartilage canals. J. Anat. (London), 98, 1964: 515-538

LEVITT, D. - DORFMAN, A.: Concept and mechanism of cartilage differentiation. In: Current Topics in Developmental Biology. Ed: Moscona and Monroy, Academic Press, New York, London, 1974

LONGMORE, R. B.-GARDNER, D. L.: Development with age of human articular cartilage surface structure. Ann rheum. Dis., 34, 1975: 26-37

LONGMORE, R. B. - GARDNER, D. L.: The surface structure of ageing human articular cartilage: A study by reflected light interference microscopy. J. Anat. (London), 126, 1978: $353-365$.

LUF TI, A. M.: The mole of growth, fate and fuction of cartilage canals. J. Anat. (London), 106, 1970: 135-145

MAROUDAS, A.-EVANS, H.-ALMZIDA, L.: Cartilage of the hip joint. Ann. rheum. Dis., 32, 19/3: 1-9

McCONAILL, M. A.: The movements of bones and joints. The mechanical structure of articulating cartilage. J. Bone Jt Surg., 33 B, 1951: 251-257

McCU TCHEN, C. W.: Boundary lubrication by synovial fluid: demonstration and possible osmotic e xplanation. Fe 1. Proc., 25, 1966: 1061

MEACHIM, G.-STO LKWELL, R. A.: Adult articular cartilage. Ed: M. A. R. Freeman, Alden Pres, Oxford, 1973

MEACHIM, G.-FERGIE, I. A.: Morphological patterns of articular cartilage fibrillation. J. Pathol, 115, 1975: 231-240

MEACHIM, G. -S TOJKWZLL, R. A.: The matrix. In: Adult articular cartilage. 2nd edition. Ed: M. A. R. Freem in, Pitm in Medical, Lon lon, 1979

MOSHURCHAK, E. M. - GHADIALLY, F. N.: A maturation change detected in the semilunar cartilages with the scanning electron microscope. J. Anat. (London), 126, 1978: 605-618

O'RAHILLY, R.-GARDNER, E.: The timing and sequence of events in the development of the limbs in the human embryo. Anat. Embryol., 148, 1975: 1-23

PALFREY, A. J.-DAVIES, D. V.: The fine structure of chondrocytes. Am. J. Anat., 100, 1966: $213-228$

PORTER, K. R.-TUCKER, J. B.: The ground substance of the living cell. Sci Ann., 244, $1981: 56-67$

PÚSCHMANN, H.: Scanning and transmission electron microscopic studies of the development of the joint surfaces. Anat. Anz., 143, 1978: 399-406

REVEL, J. P. - HAY, E. D.: An autoradiozraphic and electron microscopic study of collagen synthesis in differentiating cartilage. Z. Zellforsch., 61, 1963: 110-144

ROBERTS, K.-HYAMS, J. S.: Microtubules. Academic Press, New York, London, 1979

SHELLDON, H. - KIMBALL, F. B.: Studies on cartilage. III. The occurrence of collagen within vacuoles of the Golgi apparatus. J. Cell Biol., 12, 1962: 559-613

SCHERFT, J. P.: The lamina limitans of the organic matrix of calcified cartilage and bone. J. Ultrastruct. Res., 38, 1972: 318-331

SCHERFT, J. P.-DAEMS, W. Th.: Single cilia in chondrocytes. J. Ultrastruct. Res., 19, 1967: $546-555$

STINGL, J.: Ultrastruktura synoviálních struktur $\mathrm{v}$ časné ontogeneze člověka. Sborník prací III. kongr. o sportovní traumatologii, Třeboň, 1982 
STOCKWELL, R. A.: The cell density of human articular and costal cartilage. J. Anat. (London), 101, 1967: 753-763

STOCKWELL, R. A.: The ultrastructure of cartilage canals and the surrounding cartilage in the sheep fetus. J. Anat. (London), 109, 1971: 397-410

STOCKWELL, R. A.-MEACHIM, G.: Adult articular cartilage. Ed: M. A. R. Freeman, Alden Press Oxford, 1973

STOCKWELL, R. A. - MEACHIM, G.: The chondrocytes. In: Adult articular cartilage. 2nd edition. Ed: M. A. R. Freeman, London, Pitman Medical 1979

VIDINOV, N. - VASILEV, V.: Cilia in rat articular chondrocytes. Anat. Anz, Jena, 158, 1985: $51-55$

VIGNON, E.-ARLOT, M.-PATRICOT, L. M.-VIGNON, G.: The cell density of human femoral head cartilage. Clin. Orthop., 121, 1976: 303-308

WEISS, C. - ROSENBERG, L.-HELFET, A. J.: An ultrastructural study of normal young adult human articular cartilage. J. Bone Jt Surg. 50 A, 1968: 663-674

WEISS, C. - MIRROW, S.: An ultrastructural study of osteoarthritic changes in the articular cartilage of human knees. J. Bone Jt Surg., 54 A, 1972: 954-972

WILTBERGER, H. - LUST, G.: Ultrastructure of canine articular cartilage: comparison of normal and degenerative (osteoarthritic) hip joints. Am. J. Vet. Res., 36, 1975: 727-740

WOLF, J.: Chondrosynoviální blanka a její význam. Sborník lékařský, Praha, 48, 1946: 277-286

WOLF, J.: Chondrosynovial membrane serving as joint cavity lining with a sliding and barrier function. Folia morphol. (Prague), 17, 1969: 291-308

WOLF, J.: Function of chondral membrane of surface of articular cartilage from point of view of its mechanical resistance. Folia morphol. (Prague), 23, 1975: 77-87

ZIMNY, M. L.-REDLER, I.: Scanning electron microscopy of chondrocytes. Acta Anat. (Basel), 83, 1972: 398-402 
Plate VII.

Horký D.: Submicroscopic structure of articular... Plates VII to XVI, pp. 15-30.

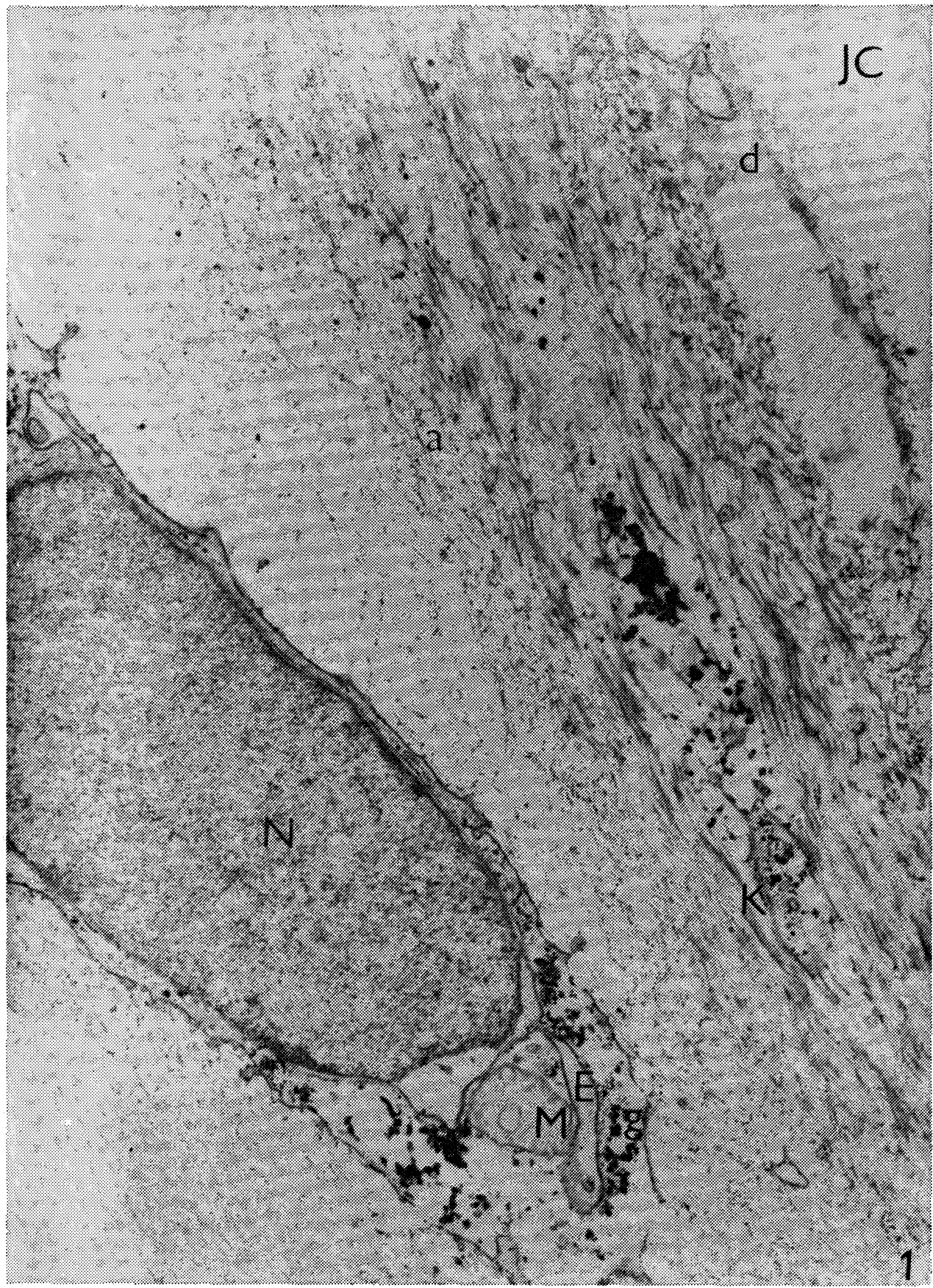

Plate VII., Fig 1 Part of surface layer of human articular cartilage 6 weeks after fertilization. Chondroblast nucleus $(\mathrm{N})$, narrow zonula nucleum limitans $(\mathrm{z})$, perinuclear space broadens and passes into cisternae of granular endoplasmic reticulum (E). Mitochondria (M) with tubular cristae glycogen (g). Joint cavity (JC), surface of articular cartilage with cellular detritus (d). Collagenous fibrils (K), aperiodic fibrils (a). Magnification: $12000 \times$ 
Plate VIII.

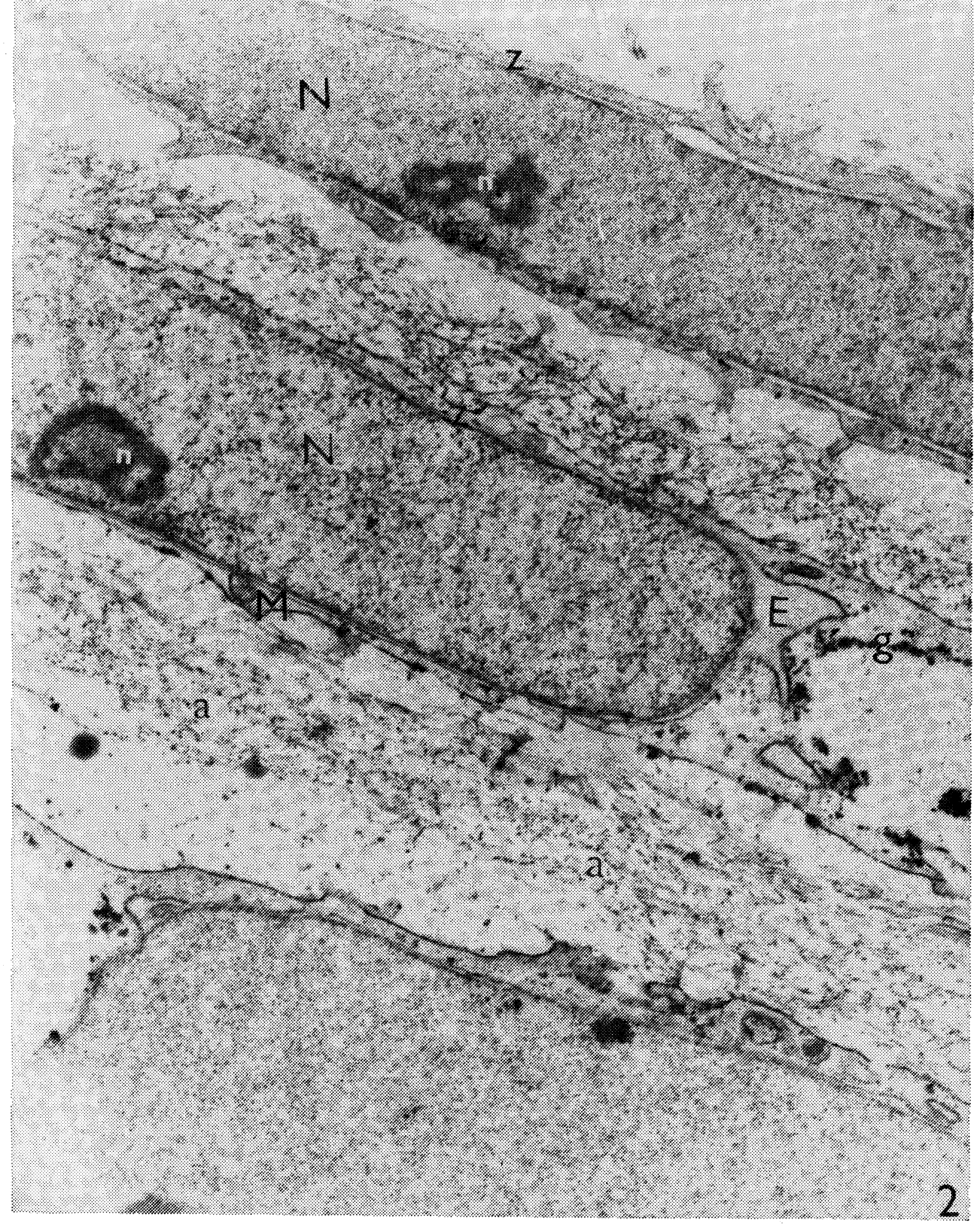

Plate VIII., Fig. 2 Chondroblasts of human articular cartilage six weeks after fertilization. Nucleus (N), nucleoli (n), zonula nucleum limitans (z), cisternae of granular endoplasmic reticulum (E) disjunct from the outer membrane of the nuclear envelope. Small mitochondria $(M)$, glycogen (g). Intercellular substance with aperiodic fibrils (a). Magnification: $16000 \times$. 
Plate IX.



Plate IX., Fig. 3 A segment of a chondroblast with intercellular substance of articular cartilage from the same stage of development. Nucleus $(\mathrm{N})$, zonula nucleum limitans $(\mathrm{z})$, broadened perinuclear space passing into granular endoplasmic reticulum (E), Golgi complex (G), smooth vesicles $(\mathrm{V})$, vacuoles with granulated content $(\mathrm{S})$, glycogen (g). Cytoplasmic processes (c) reaching into the light district $(\mathrm{pm})$, aperiodic fibrils (a) in amorphous ground substance (za). Magnification: $16000 \times$. 


\section{Plate X.}

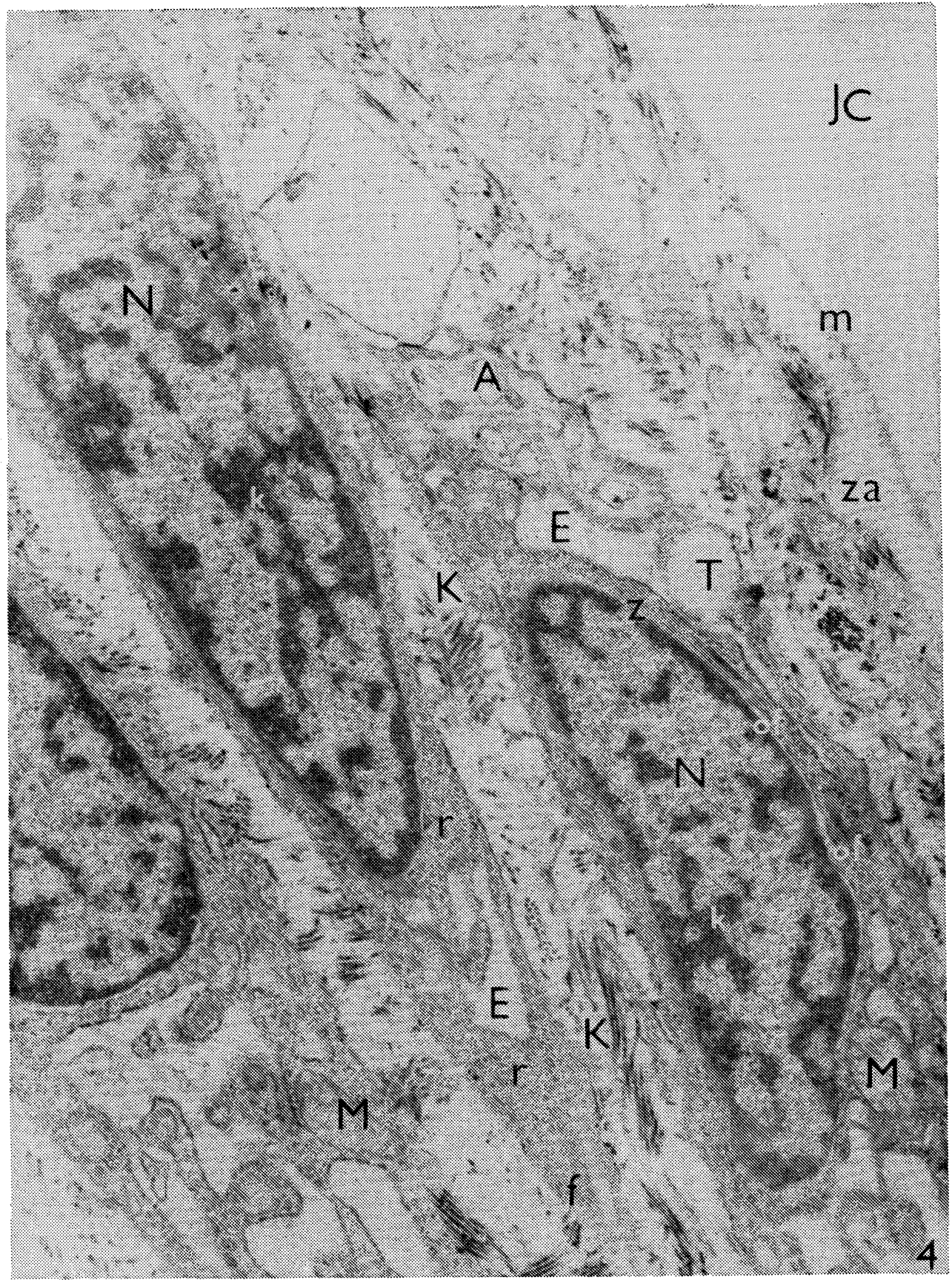

Plate X., Fig. 4 Surface layer of human articular cartilage, 8 to 11 weeks after fertilization. Nuclei of chondroblasts $(N)$, karyosomes $(K)$, zonula nucleum limitans $(z)$. Dilated cisternae of granular endoplasmic reticulum (e), agranular endoplasmic reticulum (A), mitochondria $(\mathrm{m})$, numerous polyribosomes (r). Lipid droplets ( $T$ ), cytoplasmic filaments (f), bundles of osmiophilic filaments (of). Collagenous fibrils (K) in intercellular substance, amorphous ground substance (za), with signs of densification on the surface, joint cavity (JC). Magnification: $16100 \times$. 
Plate XI.

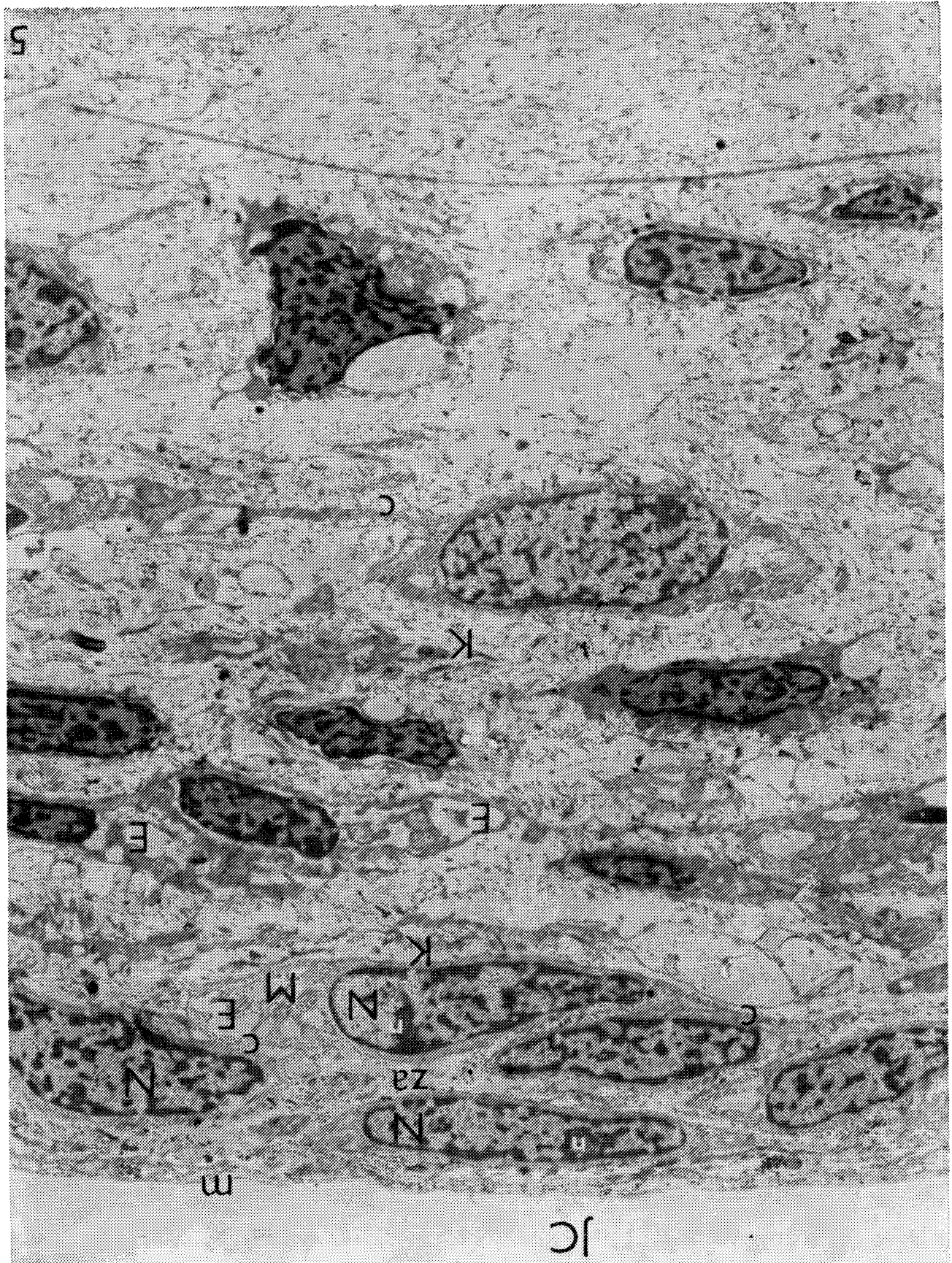

Plate XI, Fig. 5 Human articular cartilage, 8 to 11 weeks after fertilization. It shows the surface layer with numerous chondroblasts of a spindle-like shape. In their cytoplasm nuclei $(N)$, ring-like nucleoli $(n)$. Dilated cisternae of granular endoplasmic reticulum (E), mitochondria (M). Processes of cytoplasm which keep the cells in contact (c), joint cavity (JC), collagenous fibrils in intercellular substance $(\mathrm{K})$. Abundant amorphous ground substance (za) densifies on the surface to form chondral membrane (m). Magnification: $5600 \times$. 
Plate XII.



Plate XII., Fig 6 Chondroblast of the middle layer of human articular cartilage, 8 to 11 weeks after fertilization. Nucleus $(\mathrm{N})$, zonula nucleum limitans ( $\mathrm{z}$ ). Flattened cisternae of granular endoplasmic reticulum $(\mathrm{E})$ broaden to form interconnected vesicles filled with granulated material. Golgi complex (G) extends over several fields. Vesicles and transport vacuoles containing some material separate from it. Mitochondria (M), glycogen (g). Processes of cytoplasm (c) are short and extend into the surrounding intercellular substance, where amorphous component (za) with thin meshworks of aperiodic fibrils (a) predominates. Magnification: $16100 \times$. 
Plate XIII.

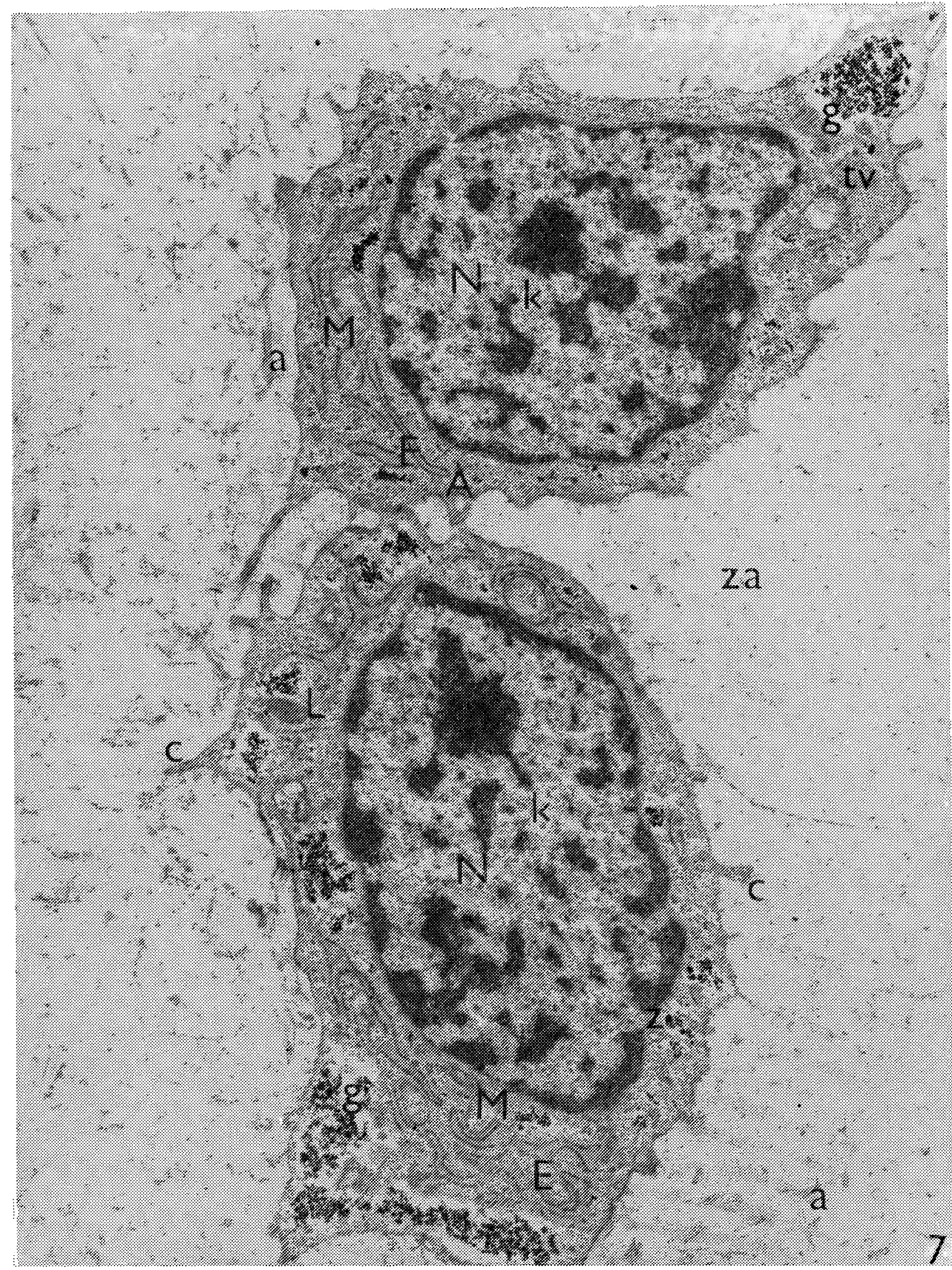

Plate XIII., Fig. 7 A pair of chondrocytes from the middle layer of human articular cartilage, 8 to 11 weeks after fertilization. Nucleus $(N)$, karyosomes $(k)$, zonula nucleum limitans $(z)$. Cisternae of granular endoplasmic reticulum (E), vesicle of agranular endoplasmic reticulum (A), transport vacuoles (tv) filled with granulated material, mitochondria (M), lysosome (L), glycogen (g). Aperiodic fibrils (a) set in abundant amorphous component (za) occur in intercellular substance. Cytoplasmic processes are infrequent and short (c). Magnification: $12000 \times$. 
Plate ẌIV.

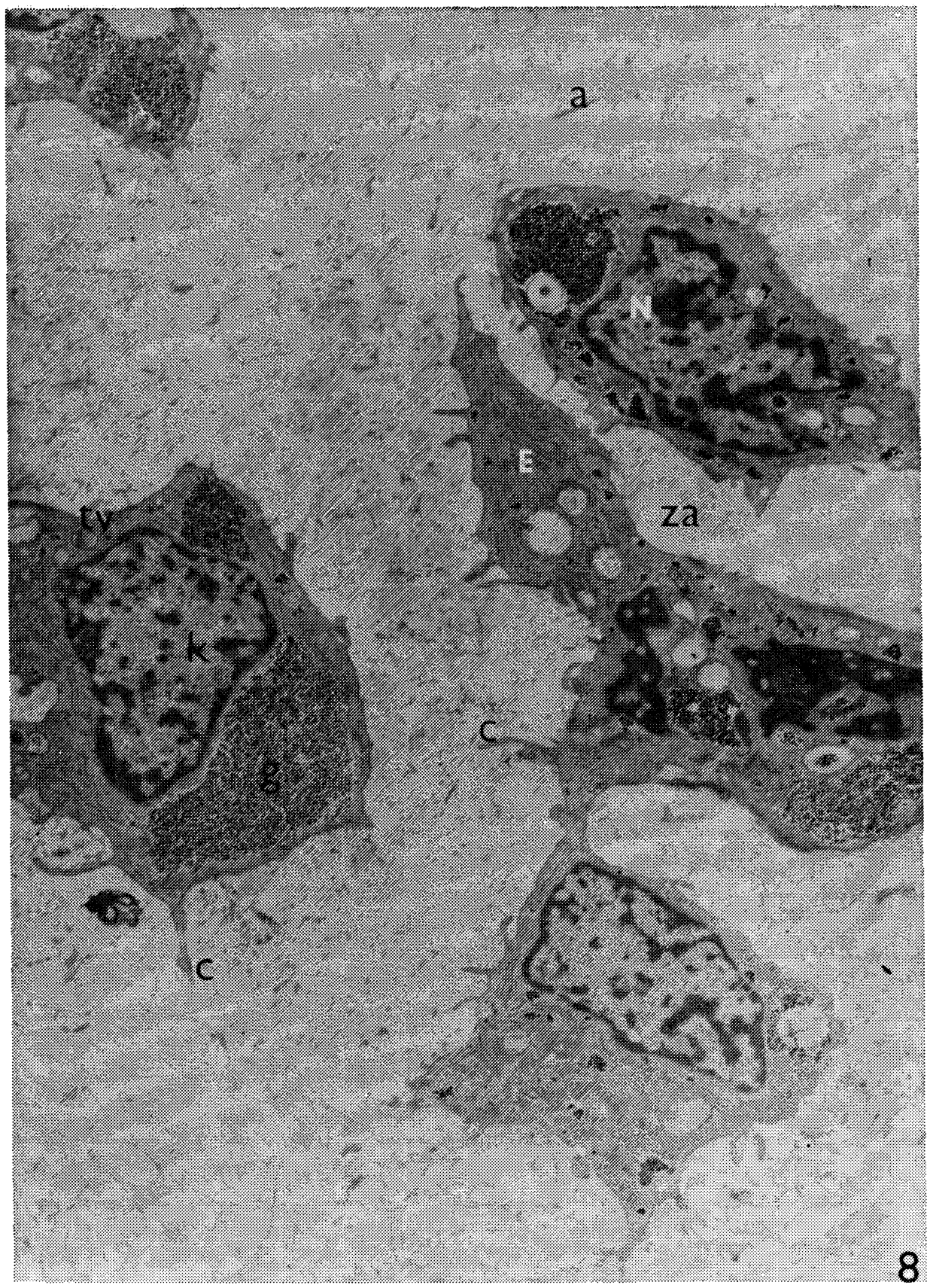

Plate XIV., Fig 8 A group of chondroblasts from the deep layer of human articular cartilage, 8 to 11 weeks after fertilization. Nuclei of irregular shape $(\mathrm{N})$ with tiny karyosomes $(k)$. Flattened cisternae of granular endoplasmic reticulum (E), transport vacuoles (tv), glycogen (g). Cytoplasmic processes extend into intercellular substance (c). Magnification: $6400 \times$. 
Plate XV.

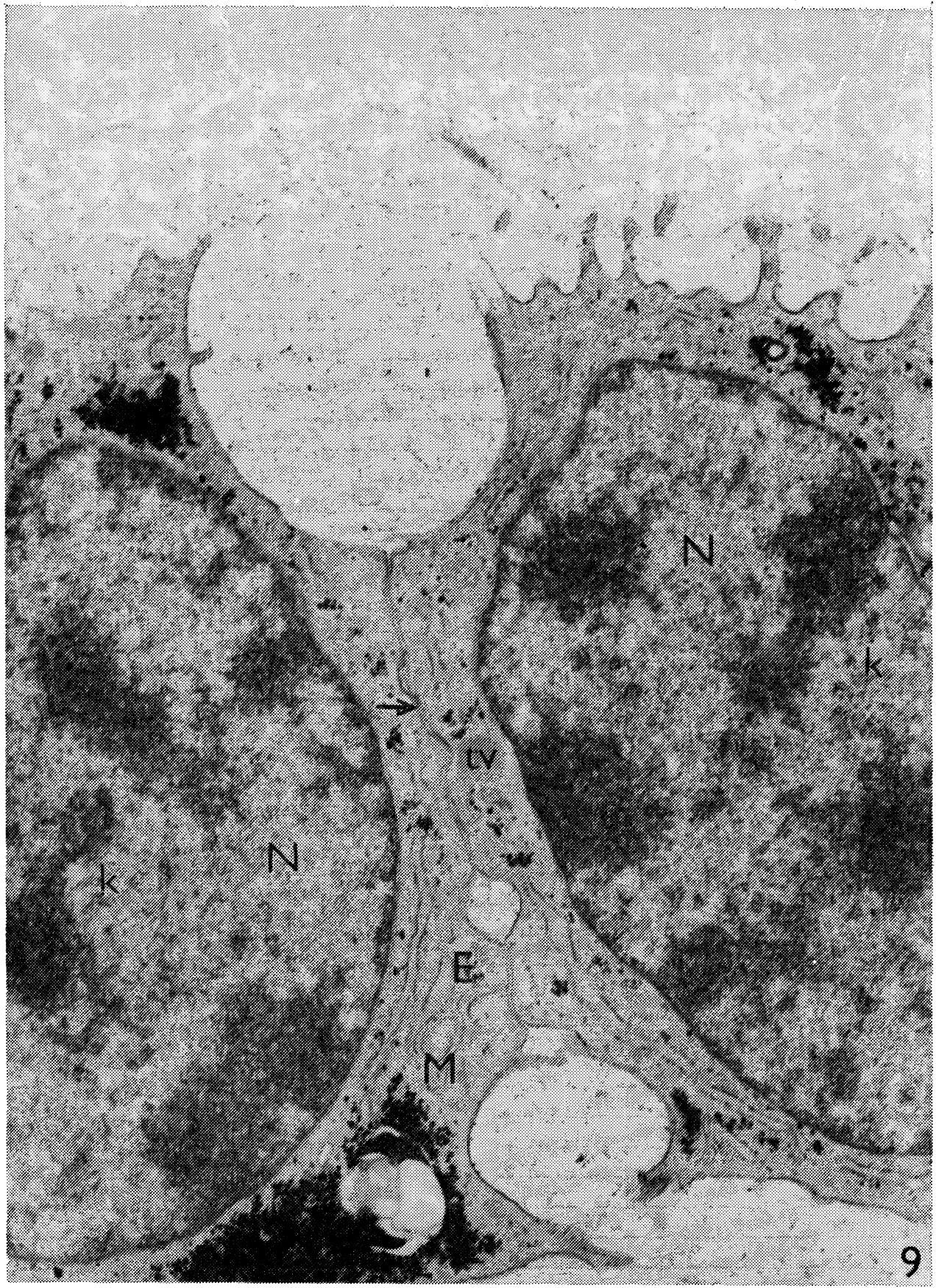

Plate XV., Fig. 9 A pair of chondroblasts from the same layer, 8 to 11 weeks after fertilization. Nucleus (N), karyosomes (k), granular endoplasmic reticulum (E), mitochondria $(M)$, transport vacuole (tv). In the area of contact between cells, first signs of zonula adherens appear ( $-{ }_{-}$. Magnificiaton: $20000 \times$. 


\section{Plate XVI.}
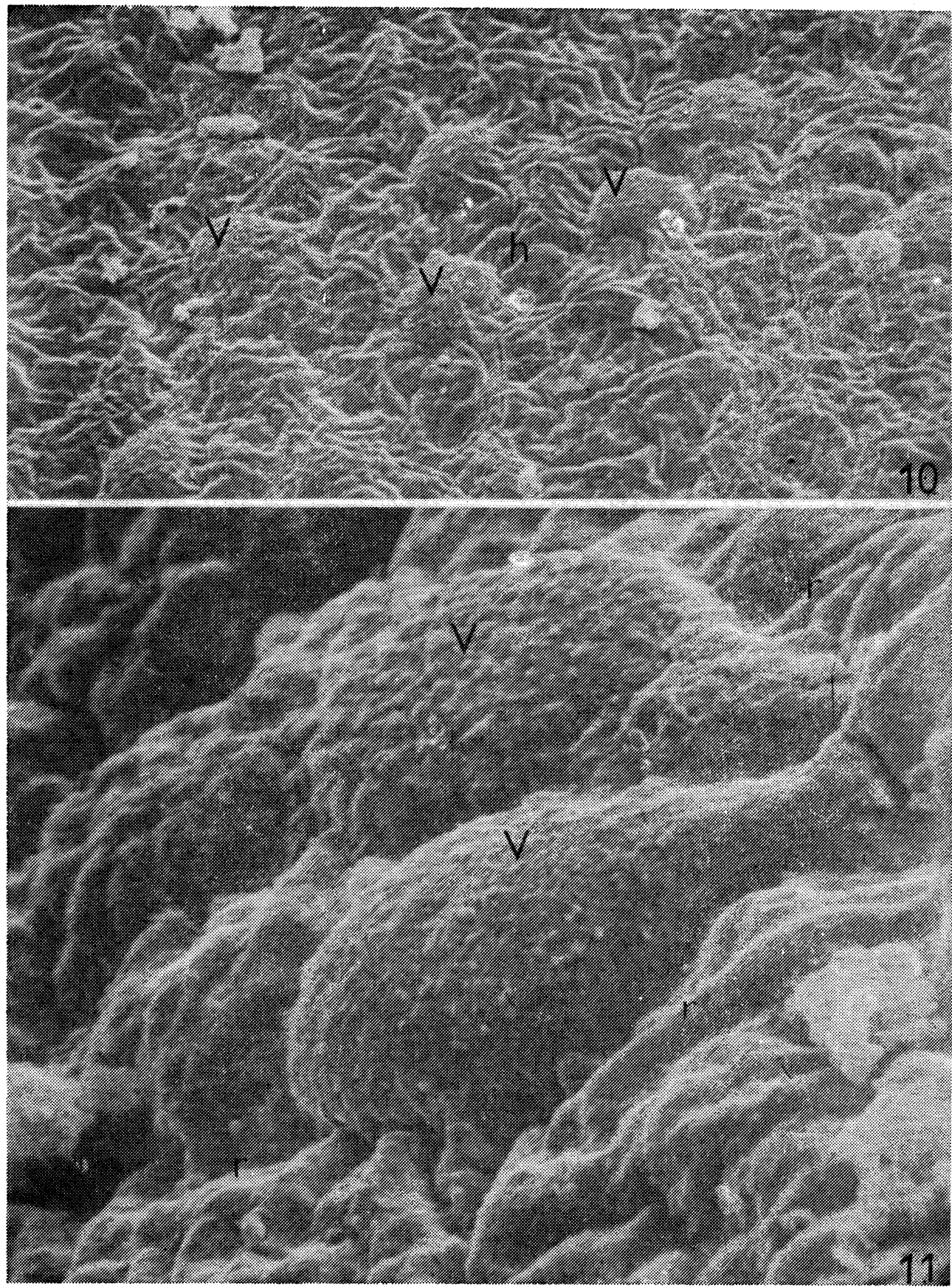

Plate XVI., Fig. 10 Surface of human articular cartilage, 8 weeks after fertilization. Numerous rounded ridges $(V)$ are prominent, with grooves between them $(h)$. Scanning electron microscopy. Magnification: $2000 \times$.

Fig. 11 Detailed view of human articular cartilage, 11 weeks after fertilization. A pair of chondroblasts $(V)$ rising prominently above the surface and overlapped with intercellular substance which is folded ( $\mathbf{r}$ ) in the area between neighbouring ridges. Scanning electron microscopy. Magnification: $10000 \times$. 